\title{
Potential Economic Value of Water Resource Sustainability for Sustainable Environment: A Case Study in South Sumatra, Indonesia
}

Restu Juniah ( $\square$ restu_juniah@yahoo.co.id )

sriwijaya university

Muhammad Taufik Toha

Sriwijaya University: Universitas Sriwijaya

Syaifudin Zakir

Sriwijaya University: Universitas Sriwijaya

Hisni Rahmi

STTIND: Sekolah Tinggi Teknologi Industri Padang

\section{Research}

Keywords: Water resource sustainability, Extended cost-benefit analysis, Erosion value, Domestic water value, Raw water value

Posted Date: May 11th, 2021

DOI: https://doi.org/10.21203/rs.3.rs-497953/v1

License: (c) (i) This work is licensed under a Creative Commons Attribution 4.0 International License. Read Full License 


\section{Abstract}

Effective water resource management offers a very significant value across social, economic, commercial and environmental application. For this fundamental reason, adequate sustainability becomes equally crucial. Therefore, activities geared towards the depletion in quantity, quality, and loss of potable water resources, particularly for communities, demand urgent reconsiderations. Erosion in coal mining land causes depletion in water quantity and quality, as well as inadequate drinking water resources for surrounding communities, making water resources unsustainable. Meanwhile, reclamation reduces erosion, but is unable to restore water depletion optimally, thus, these resources remain unsustainable. these resources remain unsustainable. However, recycling depleted water utilization for drinking provides economic value for the environment, as well as the community's drinking water resources' availability and sustainability. The objectives of this study were to develop water resource sustainability concept for a sustainable environment by analyzing the potential economic value and secondly, calculate the water resource value due to erosion, reclamation, domestic and economic importance, by recycling efforts. The method used in this study was the Extended NPV. Furthermore, the total potential economic value of water resources loss resulting in water resource unsustainability was IDR $1,137,621,671,375$ or IDR 1.14 trillion, while the potential economic value of depleted water utilization for drinking was IDR $2,298,339,797,000$ or IDR 2.3 trillion. Therefore, this utilization provides potential economic value worth IDR 1.16 trillion, for the resources' sustainability in the TAL area of PTBA. The study's results found and recommended depleted water utilization for drinking as a suitable method to replace water resources lost due to erosion, community drinking water resource loss, and to discover a sustainable environment's water resources sustainability concept. In addition, the study formulates environmental economics as a new mining science related to natural resource economics as well as mining, for sustainable water resources and mining environment.

\section{Introduction}

Sustainability appears as the most important consideration of natural resource management policy in mining as well as forms the basic principle of environmental science. Therefore, there is a great need to preserve this water resource sustainability for a balanced environment [1,2]. Also, there is no denial the mining of natural supplies tends to substantially enhance economy development, generate extensive foreign exchange [3-9], create jobs, increase income, and serve as a potential income source for communities [3,10-15]. Moreover, mining provides raw materials to build infrastructure and serve other industries, as well as generates large energy quantity, and others products $[13,16]$. However, the sector is one of the major contributors to environmental degradation [3, 5, 17-19], and therefore, resulting to deficient water resources and ecosystems.

Forest clearing is responsible for erosion, river sedimentation, silting and turbidity $[7,20-23]$ with significant impact on surface and groundwater supplies [24, 25]. This activity also influences downstream regions, resulting in a decreased marine quality [26], and in addition, eliminates water resource ecosystem services for mining communities [23, 27-29], alongside instigating scarcity [30]. The 
limited fresh water availability implies less consumption [28, 31, 32]. Water resources are very important in sustaining economic development [33] and the entire mining operations require extensive supplies directly or indirectly [32]. This situation illustrates the importance of water for the overall survival of humans and living organisms [34]. Furthermore, mining impact potentially instigates deficient hydrological function of forest as a catchment area, leading to a significant loss of water resource economic value $[13,21]$. Therefore, collaborative approach is required between hydrologists and economists to optimize the water value instruments [27] and mining resource analysis, due to these shortfalls [32] .

As a consequence, environmental damage is potentially repaired by reclamation [5]. This process is also capable of reducing erosion and protecting soil degradation [35]. However, possible occurrence is greatly decreased by cultivating legium cover crops (LCC) in early vegetation stages [36-41]. Based on this study, mine reclamation demonstrated the robust capacity to restore environmental degradation, but was unable to completely reform the depleted water resources. Therefore, recycling appears as a crucial necessity, and also aids the improvement of water efficiency [42]. Furthermore, economic valuation is highly demanded as natural resources and environment continue to diminish in monetary value $[13,29$, 43]. In addition, cost-benefit analysis (BCA) serves as a comprehensive approach to assess the net impact on social, economic, and environmental aspects, as well as an effort to protect natural resources and communities [13,44-47]. Also, BCA is used to engage water resource assessments for domestic purposes [29]. However, by evaluating the potential economic value, sustainability is easily analyzed, and with these provisions, environmental continuity and potable water supplies is adequately conserved. This circumstance agrees with the natural resource management policy, where mining natural resources is conducted while maintaining sustainability and environmental balance [2].

The purpose of this study is to develop water resource sustainability concept for a sustainable environment by analyzing the potential economic value of lost and recovered water supplies in mining areas, surrounding communities, and possible domestic use. In addition, the potential is evaluated by the extended NPV. Therefore, the water resources and coal mining environment are expected to remain potable and also sustainable.

\section{Material And Methods}

\section{Study area}

This study was directly carried out in the coal mining of Tambang Air Laya (TAL) at PT Bukit Asam Persero Tbk, Muara Enim Regency, South Sumatra Province (Fig. 1).

\section{Cleared and reclaimed land, depleted water volume}

The cleared and reclaimed land, as well as depleted water volume were 3,106.59 ha, 1,374.5 ha and $48,738,366 \mathrm{~m}^{3}$, respectively.

\section{Methods}


This exploratory research employed the extended net present value (NPV) development model. The approach is useful in conducting economic valuation, in order to determine the economic value of water resource sustainability in coal mining. Quantitative techniques were applied to calculate the NPV of benefits and external costs of open coal mining on the value of water resources ecosystem services by these assessments.

\section{Economic valuation using the Extended NPV method}

Erosion value (potential economic value of water resources lost due to erosion)

The erosion value was possibly calculated using the extended cost-benefit analysis (extended NPV), developed by [48].

$$
\text { Extended } N P V_{n e}=\sum_{t=0}^{n} \frac{B_{n p e}-C_{n p e}}{(1+r)^{t}}
$$

where:

NPVne $=$ Net Present Value

$=$ The erosion value is derived from the erosion recovery value and the erosion- resisting value (IDR)

Bnpe $=$ The erosion recovery value is an external benefit of ex-mining land revegetation (IDR).

Cnpe $=$ The erosion-resisting value is an external cost of the mining clearing impact (IDR)

$\mathrm{n}=$ Mine life (production and post production)

$r=$ Discount rate $=1,2, \ldots . n$

$\mathrm{t}=$ Interest rate

The domestic water value (potential economic value for the loss of drinking water resources for the community)

Domestic water value was also evaluated using the extended NPV method. The above equation was derived from the extended benefit and cost analysis mathematical model by [48].

$$
\text { Extended } N P V_{c a d, T}=\sum_{t=0}^{n} \frac{C_{a d r, T}-M_{p a}}{(1+r)^{t}}
$$

Where:

NPV cad $=$ Net Present Value 
$=$ Domestic water cost value of the community (IDR)

Cadr $=$ Average domestic water cost per respondent (IDR)

Mpa = The number of people buying water around TAL PTBA

$\mathrm{n}=$ Mine life (production and post mining)

$r=1,2, \ldots . n$

$\mathrm{t}=$ Interest rate

$\mathrm{T}=$ Research year

The raw water value (potential economic value of water resources from utilizing (recycling) depleted water)

The raw water value was determined, using the developed method by a previous study [47].

Extended $N P V_{n a b}=\sum_{t=0}^{n} \frac{B_{a b}-C_{a b}}{(1+r)^{t}}$

Where:

NPVnab $=$ Net Present Value

= The raw water value originates from the benefit and cost estimates (IDR)

$\mathrm{Bab}=$ The raw water benefit from recycling (IDR)

$\mathrm{Cab}=$ The raw water cost from recycling (IDR)

$\mathrm{n}=$ Mine life (production and post mining)

$r=1,2, \ldots . n$

$\mathrm{t}=$ Interest rate

\section{Results And Discussion}

\section{Impact of mining on water resources and community}

Figure 2 represents the occurrence of soil erosion and water depletion, due to mining.

The above illustration showed the erosion occurrence on the ground/open land in Indonesian coal mining $(a, b)$, and water depletion(c) due to pumped outlet at TAL PT Bukit Asam Persero Tbk, Kutai site (d), 
Suriname Artisanal Gold Mining (e).

Deforestation also instigated certain changes in water consumption, resulting in an erosion, where loss of hydrological function in forest, as a catchment area, possibly occurred. This event contributed to unsustainable outcome of water resources in terms of quantity, quality, and loss of plant economic value $[13,21]$. The situation also eliminated water ecosystem services as a resource provider [18, 47], allowed sufficient space for environmental degradation [3], as well as initiated chemical, physical, and biological environmental changes $[17,18]$. Furthermore, erosion is known to decrease surface water level, remove land cover, increase deforestation rate [25,48], lower the water level, e.g in Baganuur mine, Mongolia, decline soil fertility, as well as trigger surface and groundwater pollution [5]. In addition, increased surface water runoff and sedimentation, decreased water quality, disrupted land and river transportation were observed [50]. However, an erosion of mine waste disposal, contamination of surface water, groundwater, and soil by released chemicals from the mining process, and extinction of certain species [24]. Soil erosion also occurred in open land of mining areas and river sediments [19], [21, 23], causing significant damages to flora, fauna, hydrological relationships, and soil [22]. Previous studies have reported the incident as a major challenge in coal mining [51]. Also, sedimentation results in river silting and turbidity $[18,23,51]$. However, turbidity is probably responsible in declining water quality as well as poses a major environmental problem. This condition is triggered by suspended particles, specifically sediment and soil particles from various erosion processes, as a result of human activities, e.g. mining [7]. Moreover, water quality decrease due to extensive mining presents a great risk of domestic water scarcity [30], and the impact in the downstream area in form of sediment transfer tends to lower marine quality [26]. For instance, mining in Sri Lanka is perceived to be seriously challenging, as a result of substantial degrading water resources [23]. This results in the loss of ecosystem services in providing free water for daily community consumption $[23,28,29]$. These distributions require utmost priorities in measuring the tradeoffs between economic water benefits, in terms of mining and usage [27]. Therefore, water resources necessitates protection to enable proper and general utilization, as a natural resource for society and living organisms. Furthermore, limited fresh water and groundwater by barely 3 and $30 \%$, respectively causes less consumption [28,31]. Water resources are also very essential in maintaining economic development [33].

The above points showed the importance of water to humans and entire living organisms [34]. Therefore, a collaborative approach between hydrologists and economists appears as a great necessity in optimizing the value of water instruments [27]. The analysis of water resources in mining sector is very significant as the overall mining operations require water directly or indirectly. These activities demonstrated a substantial ecological impact [32].

\section{Mine Reclamation to Restore erosion}

Reclamation in the coal mining area of TAL PT Bukit Asam Persero Tbk (Fig. 3).

The conversion of land to forest by reverting to a tree-covered landscape or establishing a commercial forestry program is a major mine reclamation alternative (Fig. 3). A typical example is the recovery of 
entire former Appalachian mines to become one of the most beautiful forests in the world [53]. This process is highly needed to restore the forest structure and function [50] as erosion barrier [17, 21, 53]. Therefore, reclamation process is believed to reduce erosion, prevent soil degradation [35], decline runoff rates, as well as increase porosity, permeability, and infiltration [55]. Moreover, erosion is possibly minimized by planting legium cover crops in early vegetation stages. Figure 4 represents the LCC cultivation in TAL PTBA reclamation zone.

Furthermore, the introduction of LCC tends to prevent and control soil erosion, enrich and protect soil, increase water availability, and also serves as an environment preservation technique [56]. The improvement of soil's physical, chemical, and biological properties is achieved by increasing aggregate stability and reducing erosion. This provides various benefits for the agro-ecosystem, including erosion and weed control, as well as nutrient management [39]. Consequently, the improvement also prevents soil erosion, nutrient leakage [36], and provides ecosystem services, including erosion control, water quality regulation, soil moisture retention, accumulation of soil organic matter and microbial biomass, weed and pest control, as well as subsequent commercial crop yields. In addition, there is a possibility to regulate climate, soil, water as well as control erosion, clean water, and weed [38]. However, mitigating soil degradation functions as a shield from raindrops and surface runoff as well as increases the organic matter [41].

The reclamation of Hanjiawan coal mine region provided certain benefits for ecological development by enhancing soil quality, fertility, forest cover, and reducing soil/water loss, while serving an important role in economic and social aspects [25]. Similar recovery in the western zone of China mine targeted ecological restoration, environmental protection, and soil erosion control. This process is potentially a significant section of the coal industry [57]. Moreover, effective reclamation offers long-term success and high mining profitability for future economic benefits. According to [5], PTBA's coal mining land reclamation was not barely for environmental improvement through conservation and protection, but also served as an economic investment activity to create harmony and social benefits for local industry, agriculture, forestry, livestock and eucalyptus plants. Furthermore, PTBA reclamation to mine closure in NPV by 2043 reported a potential economic value of USD 91,295,530 (1 USD = IDR 13,329). Meanwhile, Appalachia Kentucky instance was estimated at a total ecosystem value of $\$ 456,428,682$ [58].

The results of this study demonstrated the inability of mine reclamation to entirely restore pumped water depletion from the outlets, but was possible to repair erosion. This circumstance was due to a more effective water absorption and storage in forest land, compared to reclaimed regions. Forest land exhibited sufficient porosity and very rapid permeability. The extensive soil porosity tends to prevent surface runoff, and therefore, resulted in an increasing water infiltration to a certain capacity, prior to saturation. Moreover, forest land showed great ability to restrain erosion, compared to reclaimed portions. In addition, excessive infiltration rate was due to higher biodiversity (understory, shrubs, and trees), litter production, porosity and permeability, as well as decreased bulk density, and therefore, preventing erosion. The vegetation diversity (biodiversity) is effective in reducing rain energy and inhibiting surface runoff velocity [55]. 
Consequently, in order to increase water efficiency, recycling offers a paramount alternative [42]. This approach was adopted in TAL PTBA mine outlet as a solution in restoring water resource lost, due to depletion, and subsequently in upholding sustainability, in terms of quality and quantity. The provision was in line with natural resource management policies, where the use of natural coal resource is to needed to maintain water resource sustainability for a balanced environment [2].

\section{Economic valuation of the water resource sustainability for a sustainable environment using the extended cost-benefit analysis (Extended NPV) model}

Resources, economy, and environment are interdependent systems for an economic valuation [58]. This process was aimed at providing a monetary assessment for natural resource loss and environmental degradation impact on humans [43]. Economic valuation is very important as natural resources and the environment showed no monetary value [13]. The effort aims to provide environmental protection as the ecosystem is responsible for free natural water resource availability [47]. In addition, the instance for Spain's Urdaibai Biosphere reserve in Spain was performed, using the framework of conservation and management policies to maximize social welfare. Furthermore, economic valuation was also conducted on the quality of water bodies, agricultural production, native forest protection, biodiversity, and recreation, where the local population were willing to financially support the management plan [45]. Costbenefit analysis (CBA) serves as a comprehensive economic valuation method for net impact assessment on social, economic and environmental aspects [13,27,42,44,45]. This process was used to provide a potable water resource assessment. Previous studies stated the provisions of benefits and costs directly (financially) and indirectly (externalities) in economic, social, and environmental aspects, by the open coal mining $[5,27,44,45,57-62]$. Economic valuation in this study was performed on erosion, domestic water, and raw water values of TAL PTBA, using extended benefit and cost analysis model.

Erosion value

Based on calculations, (Formula 1), the erosion value (Extended NPVne) between 1997-2023 was specified as IDR $716,328,638,488$,- or 716 billion rupiahs, with an erosion-resisting estimate (Cnpe) of IDR $736,436,108,129$,- or 738 billion rupiahs, and an erosion recovery (Bnpe) of IDR 20,107,469,641,- or 20 billion. These results indicated the clearing of the forest by TAL PTBA coal mining triggered an erosion and therefore, eliminated the ecosystem service value, leading to an unsustainable supply by 716 billion rupiahs. This shortfall was due to the loss of forest ecosystem services as an erosion barrier, causing unsustainable water resources by 736 billion rupiahs. Furthermore, reclamation tends to reduce erosion as well as restore forest ecosystem services and sustainable water resources by 20 billion. The results of this study were in accordance with [55], where ex-coal mine recovery showed a positive influence on diminishing erosion. However, reclamation possibly obtained a water resource sustainability value of 20 billion, but the lost water resources (716 billion rupiahs) were not completely restored. The calculation of erosion-resisting and recovery values employed benefit transfer similar to previous studies, including the use of flood control estimates, based on tropical forest types in Brazilian Amazon, with resemblance to Indonesian forests [64]. 


\section{Domestic water value}

\section{a. Domestic water quality}

The sample water emanated from Enim river in TAL PTBA. Figure 5 shows the river conditions of Enim and Artisanal gold mining site in Suriname (c) [19].

Based on the above figure, Enim river was known to be highly turbid and degraded. This condition matched previous reports, where the rivers formed a component of the degradable freshwater ecosystem [65]. The result was also in accordance with questionnaire data, where $43.07 \%$ of respondents did not utilize Enim water for drinking or cooking, based on bad smell and high turbidity. This showed the sample had declined in quality. Furthermore, the present study results were supported by Enim water quality test from Muara Enim Regional Environmental Agency (2020), where the unsuitability for bathing and consumption conformed with Minister of Health Regulation No.492/MENKES/PER/IV/2010 on Requirements for Drinking Water Quality, and the Minister of Health Regulation No. 416/MENKES/PER/IX/1990 on Clean Water. However, both guidelines require a maximum turbidity value of 5 and odorless state. Meanwhile, the turbidity for Enim River at all monitoring points reflected a value above 5 , but was very stinky. A previous study also observed similar conditions unfit for consumption (ljazah, 2016). Moreover, water availability as an income source was urgently needed by surrounding communities for bathing and washing [66].

Erosion instigates the accumulation of sediments containing chemical toxins, responsible for groundwater pollution and changes in drinking water taste [3]. The water appears turbid, due to the total dissolved solids (TDS) content from dispersed colloidal particles. Consequently, turbidity is known to significantly influence water color, and the suspended material adversely affects the quality. Excessive TDS tends to increase the turbidity and alters the transparency, while high water hardness triggers a bad taste [67]. During mining, runoff sediment quantity increased and the total suspended solids (TSS) in the form of soil surface layer were removed by rainwater flow. This deposit emanated from the degraded forest land [68]. The TSS as a pollutant accesses the hydrosphere and lithosphere through surface runoffs, causing water and soil pollution. Also, the suspended materials showed an adverse impact on water quality as sun penetration reduced. However, water turbidity increased due to a decrease in the photosynthetic process, where growth disturbances for the producing organisms were observed [67]. Another TSS impact exceeding water quality standard was unable to support fishing activities [69]. Coal mining in India causes unsuitable water resources for surrounding communities [3]. Furthermore, placer gold mining was also responsible for high turbidity in Tuul river [7], as well as in Aristasal Suriname [19].

Deforestation as a result of mining revealed a significant impact on the downstream area in the form of sediment transfer [26], and instigated water pollution in terms of quality and quantity [33], inadequate clean water availability [49], and river silting, due to elevated sedimentation responsible for reducing water depth $[18,23,51]$. The impact of coal mining on water resources triggers (1) surface water runoff and changing conditions in the catchment area, 2) destruction of aquifer structure, 3 ) damaging water circulation and balance conditions, and 4) water resource contamination. Furthermore, Gujiao coal 
mining activities played an important role in declining river runoff, while for one-tonne coal, a decrease in river, surface, and base flows, with an estimation of $2.87,0.24$, and $2.63 \mathrm{~m} 3$ were observed, respectively [6]. This condition significantly influenced water resource availability as a free ecosystem service [23, 2729]. The questionnaire data indicated the elimination of ecosystem services of Enim river as a free portable water source by TAL PTBA coal mining. This impact causes the inability of the community to enjoy free supply and therefore requires payment. The charges are used to purchase water from neighbors, in form of gallon and PAM water, although the costs gradually becomes higher. In this study, domestic water value was calculated, using contingent valuation/willingness to pay approach, and a mathematical model developed from previous study by the reclamation percentage method from time horizon [48]. Based on Eq. 2 calculations, the domestic water value of surrounding community in TAL PTBA between 1997-2023 was specified as IDR 421,293,032,887 or 421.3 billion rupiahs. These findings indicate TAL PTBA coal mining was responsible for the loss of environmental benefits to the community, devoid of ecosystem services. As a consequence, potable water resources were reportedly unsustainable at 421.3 billion rupiahs.

Therefore, the overall loss of water resource economic value in similar mines was estimated at IDR $1,137,621,671,374$,- or 1.14 trillion rupiahs. This estimation was derived from the erosion and domestic water values of IDR 716,328,638,488,- or 716 billion and IDR 421,293,032,887,- or 421.3 billion rupiahs, respectively. Based on these results, significant loss was observed in water resources as an ecosystem service, resulting in an unsustainable water resources by 1.14 trillion rupiahs. However, recycling provides a potential solution in rebuilding the actual state.

\section{The raw water value from utilizing (recycling) TAL PTBA depleted water for drinking water}

Increasing water efficiency was conducted by adopting new technologies, more efficient processes, combining reuse, recycling, and finding alternative water sources [42]. The recycling of discharged water from the mine appears very useful to the native population as a domestic water source, reduces the potential for land subsidence, and conserves valuable water resources for sustainable local environmental management. In Indonesia, PT Adaro Indonesia had recycled (utilized) mine water, using water treatment plant 300 technology [47]. Subsequently, the processed potable water becomes safe for immediate consumption (Fig. 6).

Water from Eastern Kentucky underground coal mine was supplied for municipal, industrial, agricultural, or household purposes. Similar circumstance was also observed in the former West Virginia coal mine, where recycling tends to meet the local water supply needs. Baganuur, Mongolia mine water served as community and agricultural domestic sources. Furthermore, the use of Greenwood Arkansas coal mine water for drinking purposes generated economic benefits in excess of twenty million dollars. This utilization provided the benefit values for lost water resources and economics. Previous study showed the use of PT Adaro Indonesia's coal mine void water for drinking provided economic benefits of IDR $4,438,400,888,338$ ( \pm USD $369,866,740$ ) or 4.4 trillion rupiahs [47]. 
The raw water value (Extended NPVav) in this study was obtained by recycling the depleted water in TAL PTBA. This estimate originated from the raw water benefit value (Bav) and raw water cost value (Cav). Based on Eq. 3 results, Bav and Cav were evaluated as IDR 5,458,557,017,875,- or 5.5 trillion rupiahs, and $3,160,217,220,875$, - or 3.2 trillion rupiahs, respectively. In addition, the raw water value (Extended NPVba) from the use of mine water was obtained as IDR 2,298,339,797,000,- or 2.3 trillion rupiahs. These calculations indicate the recycling approach generated a water resource sustainability value of 2.3 trillion rupiahs. Therefore, the results of this study confirmed the depleted water in TAL PTBA was used for drinking purpose to provide potential economic value as well as replace the water resources. Consequently, the utilization provided economic, social, and ecological benefits for the sustainability of water resources for a sustainable environment and the maintenance of potable supplies to the community.

Table 1 generally represents the economic valuation results of benefit and cost values for the impact of TAL PTBA coal mining on the water resource sustainability for a sustainable environment. 
Table 1

The economic valuation results of benefit and cost values for the impact of TAL PTBA coal mining on the water resource sustainability for a sustainable environment

\begin{tabular}{|c|c|c|c|}
\hline $\begin{array}{l}\text { Benefits and } \\
\text { costs } \\
\text { components }\end{array}$ & $\begin{array}{l}\text { Benefit and } \\
\text { cost value }\end{array}$ & $\begin{array}{l}\text { Unit } \\
\text { (IDR) }\end{array}$ & Description \\
\hline $\begin{array}{l}\text { NPVne }=\text { Net } \\
\text { Present Value } \\
\text { (Project time } \\
32 \text { year) }\end{array}$ & $\begin{array}{l}\text { Net erosion } \\
\text { value }\end{array}$ & 716.328 .638 .488 & $\begin{array}{l}\text { The erosion value was derived from the } \\
\text { erosion recovery value and the erosion- } \\
\text { resisting value }\end{array}$ \\
\hline Bnpe & $\begin{array}{l}\text { Erosion } \\
\text { recovery } \\
\text { benefit value }\end{array}$ & 20.107.469.641 & $\begin{array}{l}\text { The erosion recovery value is an external } \\
\text { benefit of ex-mining revegetation }\end{array}$ \\
\hline Cnpe & $\begin{array}{l}\text { Erosion- } \\
\text { resisting cost } \\
\text { value }\end{array}$ & 716.328 .638 .488 & $\begin{array}{l}\text { The erosion-resisting value is an external } \\
\text { cost of the impact of forest clearing by } \\
\text { mining }\end{array}$ \\
\hline $\begin{array}{l}\text { NPVad }=\text { Net } \\
\text { Present Value }\end{array}$ & $\begin{array}{l}\text { Net domestic } \\
\text { water value }\end{array}$ & 421.293.032.887 & $\begin{array}{l}\text { The communal domestic water cost value } \\
\text { was derived from the average domestic } \\
\text { water cost value per respondent with the } \\
\text { number of people buying water around } \\
\text { TAL PTBA }\end{array}$ \\
\hline Cadr & $\begin{array}{l}\text { Average } \\
\text { domestic } \\
\text { water cost } \\
\text { value per } \\
\text { respondent }\end{array}$ & 36.931. & $\begin{array}{l}\text { Average domestic water cost per } \\
\text { respondent }\end{array}$ \\
\hline Mpa & & 1.077.338.068. & $\begin{array}{l}\text { The number of people buying water around } \\
\text { TAL PTBA }\end{array}$ \\
\hline $\begin{array}{l}\text { NPVnab }=\text { Net } \\
\text { Present Value }\end{array}$ & $\begin{array}{l}\text { Net raw water } \\
\text { value }\end{array}$ & 2.298.339.797.000 & $\begin{array}{l}\text { The net raw water value originated from } \\
\text { the raw water benefit value from recycling } \\
\text { depleted water for drinking water with the } \\
\text { cost of recycling depleted water for } \\
\text { drinking water }\end{array}$ \\
\hline $\mathrm{Bab}$ & $\begin{array}{l}\text { Raw water } \\
\text { benefit value }\end{array}$ & 5.458.557.017.875 & $\begin{array}{l}\text { Raw water benefits from recycling depleted } \\
\text { water for drinking water }\end{array}$ \\
\hline Cab & $\begin{array}{l}\text { Raw water } \\
\text { cost value }\end{array}$ & 3.160 .217 .220 .875 & $\begin{array}{l}\text { Raw water cost from depleted water } \\
\text { recycling for drinking water }\end{array}$ \\
\hline
\end{tabular}

\section{The concept of water resource sustainability for sustainable environment in mining sector}

The background in the basic principles of environmental science comprises natural, man-made, and social [1], while sustainability deeply emphasizes the priority elements. Therefore, effective utilization and management of natural resources are greatly focused on environmental and natural resource sustainability. Based on the above principle, this study obtained the concept of water resource 
sustainability for a sustainable environment in the mining sector (Fig. 8). This view was developed from a previous study [1].

Coal mining with the ability to clear forests causes erosion, as the plants tends to lose the hydrological barrier function. Also, erosion is responsible for water depletion, as the forests no longer behave as a catchment area, and decline the water quality, resulting in loss of clean water resources for surrounding communities. However, to restore the hydrological barrier role and lost resources, reclamation and utilization of depleted water for domestic use are possibly employed. This process provides economic benefits for water resource sustainability for a balanced environment. The analysis of potential economic value, based on the above concept, showed water depletion was instigated by erosion. Also, loss of drinking water resources for the proximate communities in TAL PTBA mining generated unsustainable water resources by 1.14 trillion rupiahs. Utilization (recycling) of mine water provided water resource sustainability by 2.3 trillion rupiahs. This utilization generated sustainability benefits by 1.16 trillion rupiahs.

Furthermore, the recycling of depleted water due to TAL PTBA coal mining obtained a potential economic value for water resource sustainability by 1.16 trillion rupiahs (see Fig. 7). Therefore, the water resources in the TAL PTBA and the environment tends to remain sustainable, as well as the surrounding communities.

\section{Conclusions}

The coal mining of Tambang Air Laya (TAL) PT Bukit Asam Tbk, South Sumatra province, Indonesia instigated an environmental impact, with the loss of forest area's function as an erosion barrier. In addition, a significant loss of Enim river's role as a clean water source for the surrounding communities was also reported. These circumstances resulted in unsustainable water resources at the sample location. However, mine reclamation was possible to reduce erosion, but unable to completely restore lost water resources. The recycling or utilization of depleted water for drinking purposes was not barely able to initiate a certain degree of replacement, but also obtained potential economic value for the water resource sustainability in the site area by 1.2 trillion rupiahs. Therefore, water resources remained sustainable and the sustainability of the environment and clean water resources for surrounding TAL PTBA communities appeared effectively maintained.

\section{Declarations}

\section{Acknowledgements}

The authors are grateful to Sriwijaya University and PT Bukit Asam Persero Tbk for supporting this research.

\section{Authors' contributions}


RJ prepared and revised draft manuscripts, and also involved in methodology development, formal analysis and data presentation. MTT contributes to the concept of mine reclamation. SZ contributes to socio-economic analysis. HR contributed to the presentation of the manuscript data. All authors reviewed and approved the final manuscript.

\section{Availability of data and materials}

The data used to support the findings of this study are available from the corresponding author upon request.

\section{Competing interests}

The authors declare they have no competing interests.

\section{References}

1. R. Juniah and M. Sastradinata, "Study benefit value of utilization water resources for energy and sustainable environment," AIP Conf. Proc., vol. 1903, 2017, doi: 10.1063/1.5011539.

2. S. Zakir and R. Juniah, "Natural Resource Management Policy: A Challenge for Sustainable Develompment in Indonesia," in Adverting a Global Environmental Collapse The Role of Anthropology and Local Knowledge, Cambridge Scholars Publishing, 2015, pp. 303-310.

3. N. Mishra and N. Das, "Coal Mining and Local Environment: A Study in Talcher Coalfield of India," Air, Soil Water Res., vol. 10, 2017, doi: 10.1177/1178622117728913.

4. I. Z. Rela, A. H. Awang, Z. Ramli, Y. Taufik, S. Md. Sum, and M. Muhammad, “Effect of corporate social responsibility on community resilience: Empirical evidence in the nickel mining industry in Southeast Sulawesi, Indonesia," Sustain., vol. 12, no. 4, 2020, doi: 10.3390/su12041395.

5. A. Kodir, D. M. Hartono, H. Haeruman, and I. Mansur, "Integrated post mining landscape for sustainable land use: A case study in South Sumatera, Indonesia," Sustain. Environ. Res., vol. 27, no. 4, pp. 203-213, 2017, doi: 10.1016/j.serj.2017.03.003.

6. J. Ping, S. Yan, P. Gu, Z. Wu, and C. Hu, "Application of MIKE SHE to study the impact of coal mining on river runoff in Gujiao mining area, Shanxi, China," PLoS One, vol. 12, no. 12, pp. 1-18, 2017, doi: 10.1371/journal.pone.0188949.

7. B. Batsaikhan et al., "Hydrochemical evaluation of the influences of mining activities on river water chemistry in central northern Mongolia," Environ. Sci. Pollut. Res., vol. 24, no. 2, pp. 2019-2034, 2017, doi: 10.1007/s11356-016-7895-3.

8. R. Juniah, "Environmental Management and Sustainability Sustainable Mining Environment: Technical Review of Post-mining Plans," Indones. J. Environ. Manag. Sustain., vol. 1, no. 1, pp. 6-10, 2017, doi: 10.26554/ijems.2017.1.1.6-10.

9. N. M. E. Kioe-A-Sen, M. J. Van Bergen, T. E. Wong, and S. B. Kroonenberg, "Gold deposits of Suriname: Geological context, production and economic significance," Geol. en 
Mijnbouw/Netherlands J. Geosci., vol. 95, no. 4, pp. 429-445, 2016, doi: 10.1017/njg.2016.40.

10. F. R. Harahap, R. Taqwa, R. Juniah, and E. Wildayana, "Sustainability for Management and Protection Tin Mining Environment," E3S Web Conf., vol. 68, pp. 1-6, 2018, doi:

$10.1051 /$ e3sconf/20186803002.

11. C. Greene and P. C. McGinley, "Yielding to he Necessities of a Great Public Industry: Denial and Concealment of the Harmful Health Effects of Coal Mining," William Mary Environ. Law Policy Rev., vol. 43, no. 3, p. 689, 2019.

12. L. Mancini and S. Sala, "Social impact assessment in the mining sector: Review and comparison of indicators frameworks," Resour. Policy, vol. 57, no. February, pp. 98-111, 2018, doi:

10.1016/j.resourpol.2018.02.002.

13. R. Juniah, R. Dalimi, M. Suparmoko, S. S. Moersidik, and H. Waristian, "Environmental value losses as impacts of natural resources utilization of in coal open mining," MATEC Web Conf., vol. 101, pp. 4-8, 2017, doi: 10.1051/matecconf/201710104013.

14. N. R. Haddaway et al., "Evidence of the impacts of metal mining and the effectiveness of mining mitigation measures on social-ecological systems in Arctic and boreal regions: A systematic map protocol," Environ. Evid., vol. 8, no. 1, pp. 1-11, 2019, doi: 10.1186/s13750-019-0152-8.

15. M. Minaei Mobtaker and M. Osanloo, "Positive impacts of mining activities on environment," Legis. Technol. Pract. Mine L. Reclam. - Proc. Beijing Int. Symp. L. Reclam. Ecol. Restoration, Lr. 2014, pp. 7-14, 2015, doi: 10.1201/b17500-7.

16. F. P. Carvalho, "Mining industry and sustainable development: Time for change," Food Energy Secur., vol. 6, no. 2, pp. 61-77, 2017, doi: 10.1002/fes3.109.

17. R. Juniah, D. Susetyo, and H. Rahmi, "Technical Review of Land Usage of Former Limestone Mine for Rubber Plantation in PT Semen BaturajaTbk for Sustainable Mining Environment," J. Phys. Conf. Ser., vol. 1338, no. 1, 2019, doi: 10.1088/1742-6596/1338/1/012024.

18. R. Juniah, "Harmonization of Green Open Space as Carbon Assimilator for Sustainable Environment of Transportation Sector and Steam Power Plant," Sriwij. J. Environ., vol. 3, no. 1, pp. 43-46, 2018, doi: 10.22135/sje.2018.3.1.43-46.

19. K. M. Wantzen and J. H. Mol, "Soil erosion from agriculture and mining: A threat to tropical stream ecosystems," Agric., vol. 3, no. 4, pp. 660-683, 2013, doi: 10.3390/agriculture3040660.

20. J. Jarsjö, S. R. Chalov, J. Pietroń, A. V. Alekseenko, and J. Thorslund, "Patterns of soil contamination, erosion and river loading of metals in a gold mining region of northern Mongolia," Reg. Environ. Chang., vol. 17, no. 7, pp. 1991-2005, 2017, doi: 10.1007/s10113-017-1169-6.

21. Zulkarnain, B. Joy, P. Tuhpawana, and I. Prawira, "Soil Erosion Assessment of The Post-Coal Mining Site in Kutai Kartanagera District, East Kalimantan Province," Int. J. Sci. Eng., vol. 7, no. 2, pp. 130136, 2014, doi: 10.12777/ijse.7.2.130-136.

22. N. Mashud and M. Engelbert, "Utilization of Ex-Coal Mine Land for Sago Development," Bul. Palma, vol. 15, no. 1, pp. 56-63, 2016, doi: 10.21082/bp.v15n1.2014.56-63. 
23. C. B. Dissanayake and M. S. Rupasinghe, "Environmental impact of mining, erosion and sedimentation in Sri Lanka," Int. J. Environ. Stud., vol. 51, no. 1, pp. 35-50, 1996, doi: 10.1080/00207239608711069.

24. O. Agboola et al., "A review on the impact of mining operation: Monitoring, assessment and management," Results Eng., vol. 8, no. October, p. 100181, 2020, doi: 10.1016/j.rineng.2020.100181.

25. C. Yu, X. Wang, K. Pang, G. Zhao, and W. Sun, "Dynamic Characteristics of a Vibrating Flip-Flow Screen and Analysis for Screening 3 mm Iron Ore," Shock Vib., vol. 2020, 2020, doi: 10.1155/2020/1031659.

26. A. Masnang et al., "Study of Run-off and Erosion Rate on Various Land Use in The Upper Jenneberang Sub Watershed," J. Agroteknos, vol. 4, no. 1, pp. 32-37, 2014.

27. J. Ossa-Moreno et al., "The Hydro-economics of Mining," Ecol. Econ., vol. 145, no. November 2017, pp. 368-379, 2018, doi: 10.1016/j.ecolecon.2017.11.010.

28. C. Griebler and M. Avramov, "Groundwater ecosystem services: A review," Freshw. Sci., vol. 34, no. 1, pp. 355-367, 2015, doi: 10.1086/679903.

29. R. Juniah, "Void Our Friends: The Economic Value Air Void Mine As Raw Water PT Adaro Indonesia Kalsel," 2014.

30. H. Aslam, J. Liu, A. Mazher, D. Mojo, I. Muhammad, and C. Fu, "Willingness to pay for improved water services in mining regions of developing economies: Case study of a coal mining project in Thar coalfield, Pakistan," Water (Switzerland), vol. 10, no. 4, pp. 1-17, 2018, doi: 10.3390/w10040481.

31. K. Kalhor, R. Ghasemizadeh, L. Rajic, and A. Alshawabkeh, "Assessment of groundwater quality and remediation in karst aquifers: A review," Groundw. Sustain. Dev., vol. 8, no. October 2018, pp. 104121, 2019, doi: 10.1016/j.gsd.2018.10.004.

32. G. Kumar, "Impact of Coal Mining on Water Quality," National Institute of Technology, 2015.

33. Ugya AY, Ajibade FO, and Ajibade TF, "Water Pollution Resulting From Mining Activity: an Overview," Proc. 2018 Annu. Conf. Sch. Eng. Eng. Technol. (SEET), Fed. Univ. Technol. Akure, Niger. 17-19 July, 2018, no. September 2019, 2018.

34. S. Guerra-Rodríguez, P. Oulego, E. Rodríguez, D. N. Singh, and J. Rodríguez-Chueca, "Towards the implementation of circular economy in the wastewater sector: Challenges and opportunities," Water (Switzerland), vol. 12, no. 5, 2020, doi: 10.3390/w12051431.

35. M. Buta et al., "Soil reclamation of abandoned mine lands by revegetation in Northwestern part of Transylvania: A 40-Year retrospective study," Sustain., vol. 11, no. 12, 2019, doi: 10.3390/su10023393.

36. J. Park, E. Kwon, E. Chung, H. Kim, B. Battogtokh, and N. C. Woo, "Environmental sustainability of open-pit coal mining practices at Baganuur, Mongolia," Sustain., vol. 12, no. 1, pp. 1-20, 2020, doi: $10.3390 /$ su 12010248.

37. C. Agus, D. Wulandari, P. A. B. Cahyanti, I. Bantara, B. P. Hutahaean, and T. Lestari, "Environmental site engineering and integrated bio-cycles management for rehabilitation of degraded tin mining land 
in tropical ecosystem," IOP Conf. Ser. Earth Environ. Sci., vol. 398, no. 1, 2019, doi: 10.1088/17551315/398/1/012013.

38. G. E. Shackelford, R. Kelsey, and L. V. Dicks, "Effects of cover crops on multiple ecosystem services: Ten meta-analyses of data from arable farmland in California and the Mediterranean," Land use policy, vol. 88, no. September, p. 104204, 2019, doi: 10.1016/j.landusepol.2019.104204.

39. M. Hallama, C. Pekrun, H. Lambers, and E. Kandeler, "Hidden miners - the roles of cover crops and soil microorganisms in phosphorus cycling through agroecosystems," Plant Soil, vol. 434, no. 1-2, pp. 7-45, 2019, doi: 10.1007/s11104-018-3810-7.

40. E. A. Pauletto et al., "Reclamation of a degraded coal-mining area with perennial cover crops," Rev. Bras. Cienc. do Solo, vol. 40, pp. 1-13, 2016, doi: 10.1590/18069657rbcs20150482.

41. B. H. Narenda, "The Growth of Cover Crops in the Ex-Tin Mining Overburden Land on Bangka Island," For. Rehabilition J., vol. 01, no. 01, pp. 15-24, 2014.

42. I. Prosser, L. Wolf, and A. Littleboy, "Water in mining and industry," CSIRO, 2011, p. 2011.

43. D. Damigos, "An overview of environmental valuation methods for the mining industry," J. Clean. Prod., vol. 14, no. 3-4, pp. 234-247, 2006, doi: 10.1016/j.jclepro.2004.06.005.

44. T. Gunton, C. Joseph, M. Pope, and C. Gunton, "Evaluating Methods for Analyzing Economic Impacts in Environmental Assessment - KSG Report," pp. 1-35, 2020.

45. N. Castillo-Eguskitza, D. Hoyos, M. Onaindia, and M. Czajkowski, "Unraveling local preferences and willingness to pay for different management scenarios: A choice experiment to biosphere reserve management," Land use policy, vol. 88, no. August, p. 104200, 2019, doi: 10.1016/j.landusepol.2019.104200.

46. P. Krawczyk, M. Majer, and J. Krzemień, "Proposal of economic assessment of hard coal mines operation conducted in Polish conditions with the use of Cost Benefit Analysis," Arch. Min. Sci., vol. 61, no. 4, pp. 875-892, 2016, doi: 10.1515/amsc-2016-0058.

47. S. S. Moersidik, R. Juniah, S. Damayanti, Y. R. Intarti, C. Arief, and Z. R. Pratiwi, "Model of water resources sustainability: Mining void water utilization in coal mining (case study at PT. adaro Indonesia, South Borneo, Indonesia)," Int. J. Appl. Eng. Res., vol. 9, no. 9, pp. 1183-1199, 2014.

48. R. Juniah, R. Dalimi, M. Suparmoko, and S. Moersidik, "Mathematical Model of Benefits and Costs of Coal Mining Environmental," J. Sustain. Dev., vol. 11, no. 6, p. 246, 2018, doi: 10.5539/jsd.v11n6p246.

49. P. T. Mabey, W. Li, A. J. Sundufu, and A. H. Lashari, "Environmental impacts: Local perspectives of selected mining edge communities in Sierra Leone," Sustain., vol. 12, no. 14, pp. 1-16, 2020, doi: $10.3390 /$ su12145525.

50. R. Kristant, H. Kartodihardjo, B. Nugroh, and I. Mansur, "Institutional performance of mining reclamation in forest areas of east kalimantan," J. Manaj. Hutan Trop., vol. 25, no. 2, pp. 69-81, 2019, doi: 10.7226/jtfm.25.2.69.

51. A. Yamani, "Study of the magnitude of erosion in the coal mine reclamation area at PT Arutmin Indonesia, Kotabaru Regency," J. Hutan Trop., vol. 13, no. 1, pp. 46-54, 2012. 
52. A. L. Boyles et al., "Systematic review of community health impacts of mountaintop removal mining," Environ. Int., vol. 107, no. January, pp. 163-172, 2017, doi: 10.1016/j.envint.2017.07.002.

53. H. Z. Angel, C. D. Barton, M. French, and P. N. Angel, "the Appalachian Regional Reforestation Initiative and Green Forests Work: Bringing Back the Forest on Surface Coal Mines in Appalachia," J. Am. Soc. Min. Reclam., vol. 4, no. 2, pp. 91-101, 2015, doi: 10.21000/jasmr15020091.

54. C. Martín-Moreno, J. F. Martín Duque, J. M. Nicolau Ibarra, N. Hernando Rodríguez, M. Á. Sanz Santos, and L. Sánchez Castillo, “Effects of Topography and Surface Soil Cover on Erosion for Mining Reclamation: The Experimental Spoil Heap at El Machorro Mine (Central Spain)," L. Degrad. Dev., vol. 27, no. 2, pp. 145-159, 2016, doi: 10.1002/ldr.2232.

55. O. Patiung, N. Sinukaban, S. D. Tarigan, and D. Darusman, “Effect of Reclamation Age of Ex-Coal Mining Land on Hydrological Function," Hidrolitan, vol. 2, no. 2, pp. 60-73, 2011.

56. P. Sharma et al., "The Role of Cover Crops towards Sustainable Soil Health and Agriculture-A Review Paper," Am. J. Plant Sci., vol. 09, no. 09, pp. 1935-1951, 2018, doi: 10.4236/ajps.2018.99140.

57. W. Xiao, Z. Hu, and Y. Fu, "Zoning of land reclamation in coal mining area and new progresses for the past 10 years," Int. J. Coal Sci. Technol., vol. 1, no. 2, pp. 177-183, 2014, doi: 10.1007/s40789-0140024-3.

58. L. Li, Y. Lei, and D. Pan, “Economic and environmental evaluation of coal production in China and policy implications," Nat. Hazards, vol. 77, no. 2, pp. 1125-1141, 2015, doi: 10.1007/s11069-0151650-9.

59. I. Ibrahim, R. Juniah, and D. Susetyo, "Potential Utilization of Coal Mine Void Water for Micro Hydro Power Plant," J. Pertamb., vol. 4, no. 4, pp. 180-185, 2020, doi: 10.36706/jp.v4i4.570.

60. X. Álvarez, E. Valero, N. de la Torre-Rodríguez, and C. Acuña-Alonso, "Influence of small hydroelectric power stations on river water quality," Water (Switzerland), vol. 12, no. 2, 2020, doi:

$10.3390 / \mathrm{w} 12020312$.

61. Hirfan, Soemarno, E. Setyowati, and A. Tamsil, “Economic Valuation of the Post Nickel Mine Reclamation in East Luwu Regency , South Sulawesi," Resour. Environ., vol. 6, no. 6, pp. 143-147, 2016, doi: 10.5923/j.re.20160606.07.

62. E. Prasodjo, S. R. P. Sitorus, S. Pertiwi, and E. I. K. Putri, “Economic valuation of coal mining activity in Samarinda city, east Kalimantan, Indonesia," Int. J. Appl. Eng. Res., vol. 10, no. 10, pp. 26347-26362, 2015.

63. R. Gillespie and M. E. Kragt, "Accounting for Nonmarket Impacts in a Benefit-Cost Analysis of Underground Coal Mining in New South Wales, Australia," J. Benefit-Cost Anal., vol. 3, no. 2, pp. 1-29, 2012, doi: 10.1515/2152-2812.1101.

64. D. Sudirman, "Optimization of Compensation Costs for Environmental Damage for Coal Mining Activities in Protected Forests," Universitas Indonesia, 2011.

65. P. F. M. Verdonschot, G. H. van der Lee, and R. C. M. Verdonschot, "Integrating measures of ecosystem structure and function to improve assessments of stream integrity," Freshw. Sci., vol. 39, no. November 2019, pp. 1-51, 2020. 
66. R. Juniah and H. Rahmi, "The influence of sand mining towards the sustainability of power support and capacity of Lambidaro River," AIP Conf. Proc., vol. 1903, 2017, doi: 10.1063/1.5011534.

67. F. Z. ljazah, D. Rohmat, and Y. Malik, "Impact of Coal Mining Activities on Enim River Water Quality in Lawang Kidul District," Antol. Pendidik. Geogr., vol. 4, no. 2, pp. 1-14, 2016.

68. Supriyono, P. Iskarni, and E. Barlian, "Study of the Impact of Coal Mining on Water Quality and Direction of River Mitigation Policies in the Sub-Basin Downstream of the Bengkulu River," J. Geogr. Univ. Negeri Padang, vol. 4, no. 2, pp. 185-197, 2015.

69. E. Iriadenta, "Management and Revitalization Strategy Study of Water Resources Utilization of Void Mine / Ex-Coal Mining Reclamation PD. Bramarta Banjar District Based on Community Empowerment," 2010.

\section{Figures}

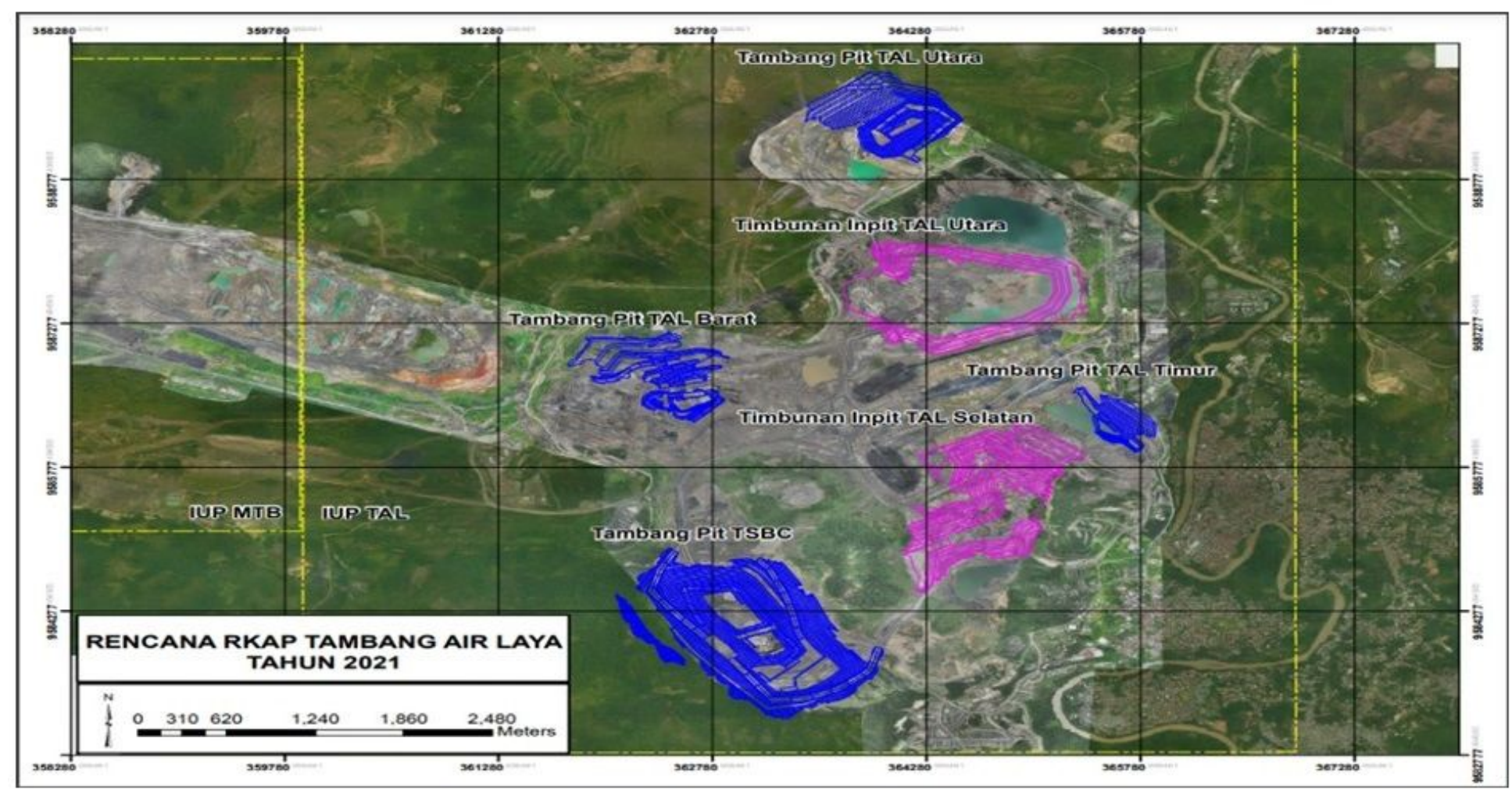

\section{Figure 1}

Research Location. Note: The designations employed and the presentation of the material on this map do not imply the expression of any opinion whatsoever on the part of Research Square concerning the legal status of any country, territory, city or area or of its authorities, or concerning the delimitation of its frontiers or boundaries. This map has been provided by the authors. 


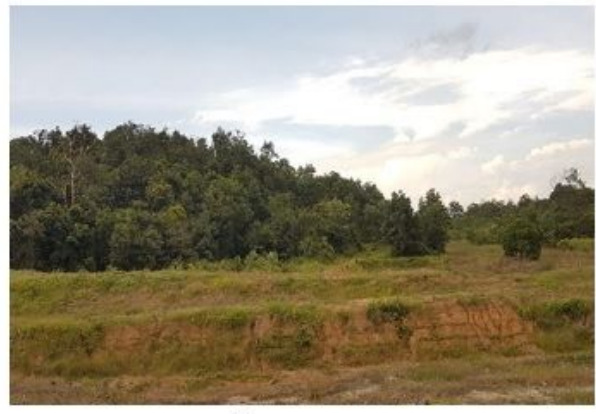

a

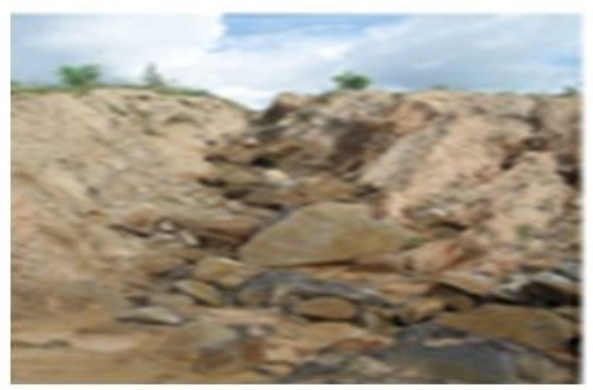

d

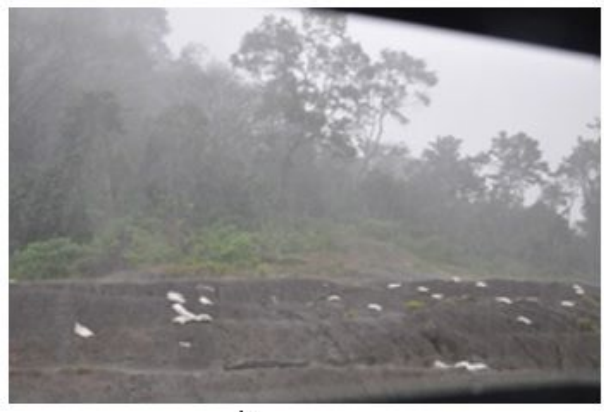

b

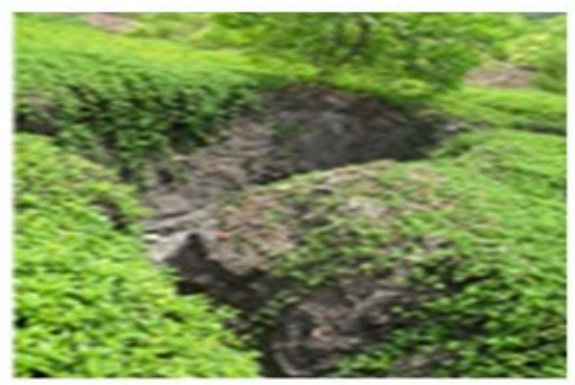

e

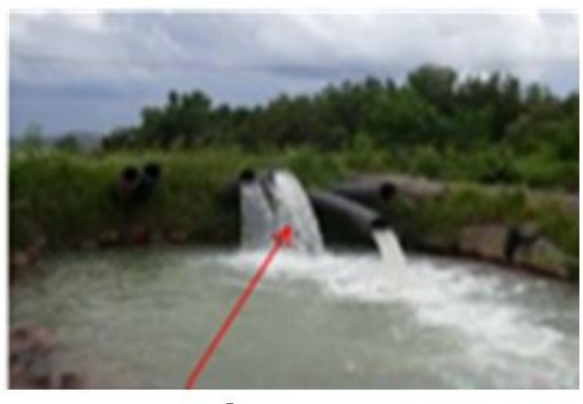

c

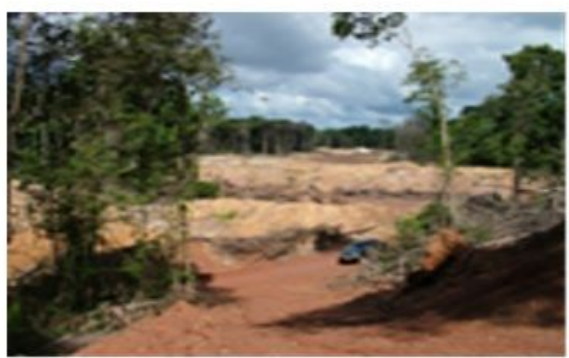

f

Figure 2

Land erosion and water depletion

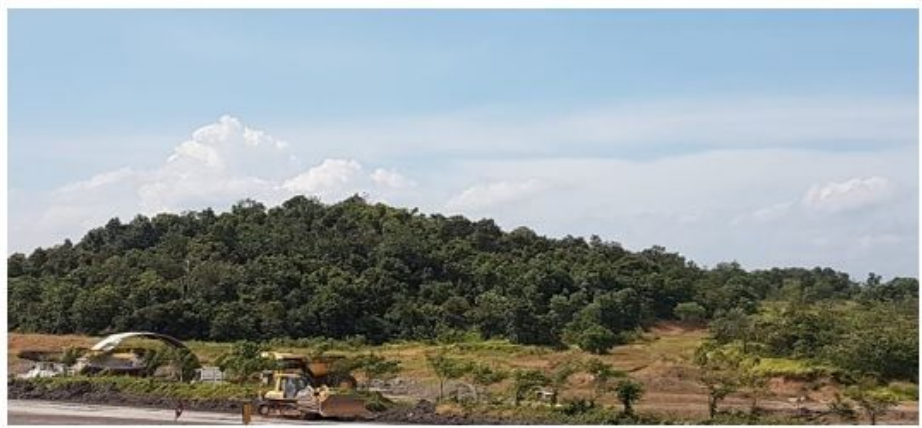

a

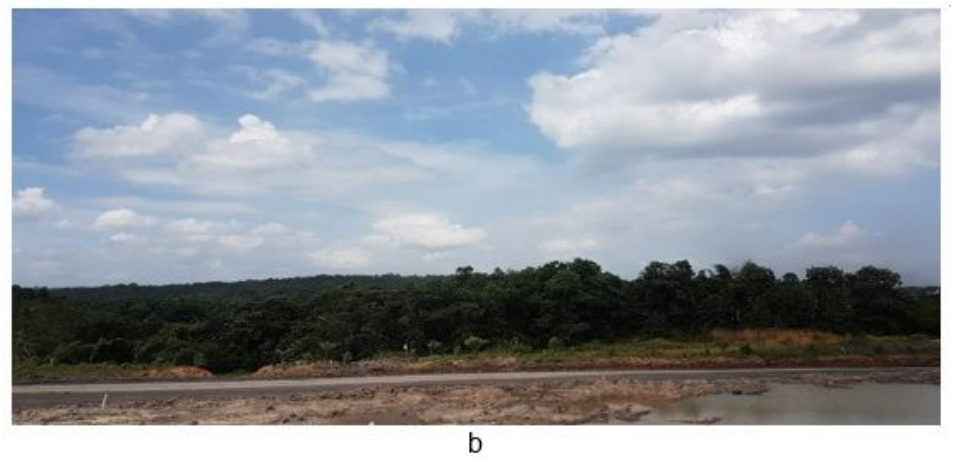

Figure 3

Reclamation of TAL PTBA

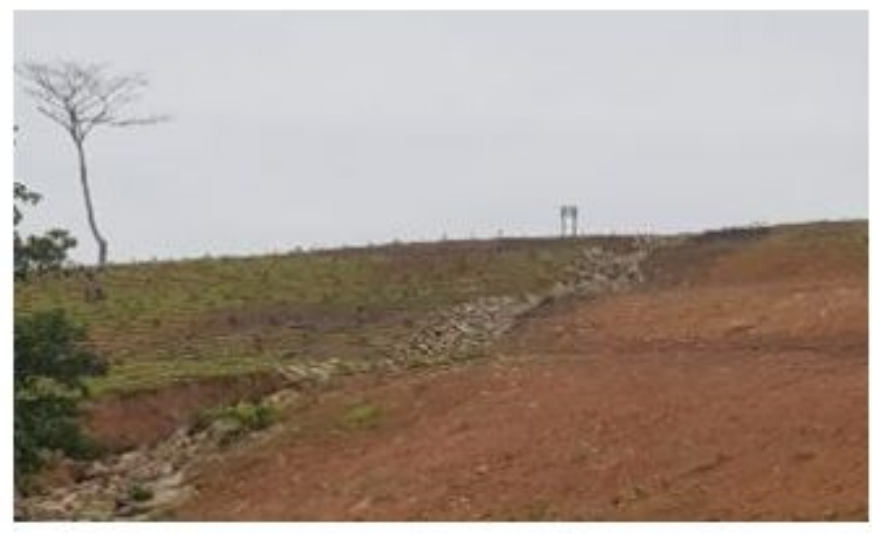

a

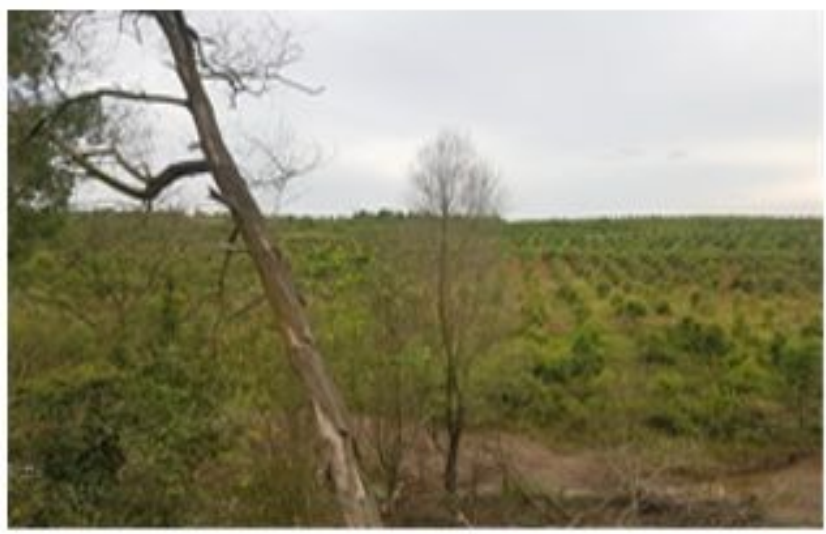

b 


\section{Figure 4}

Planting of legume cover crops at PTBA Tambang Air Laya

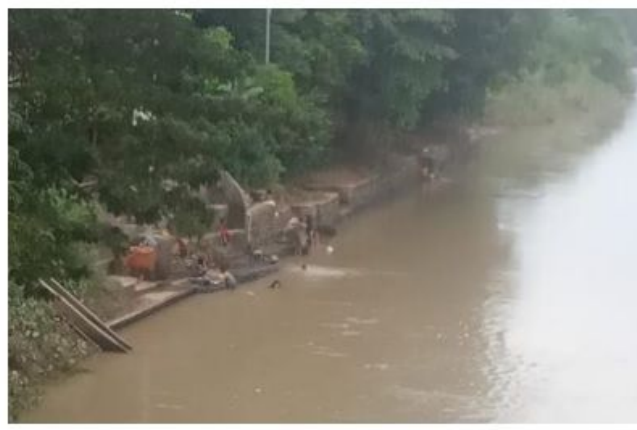

a

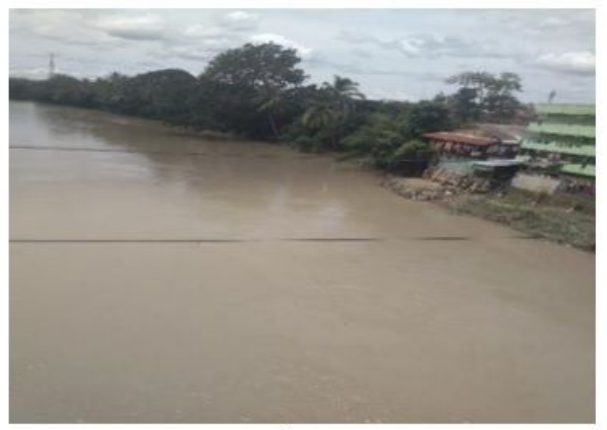

b

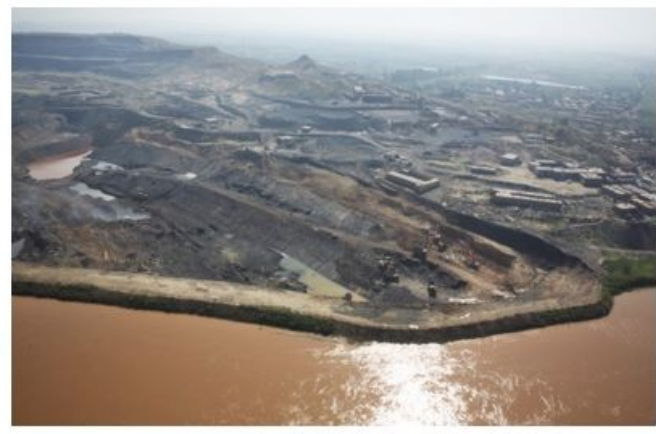

$\mathrm{c}$

\section{Figure 5}

The condition of PTBA Enim river $(a, b)$, and China's coal industry polluting the Yellow River basin (c) Green Peace, 2014

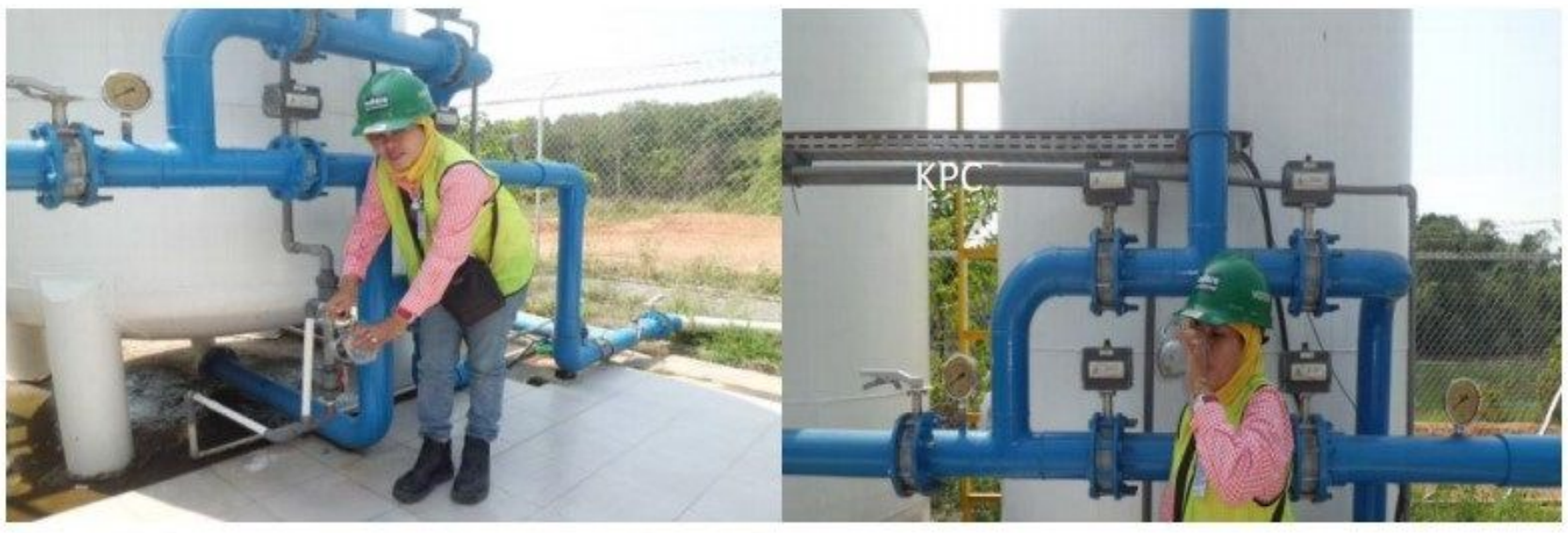

\section{Figure 6}

The processed mine void wastewater of PT Adaro Indonesia that can be consumed directly 


\section{Trillion (IDR)}

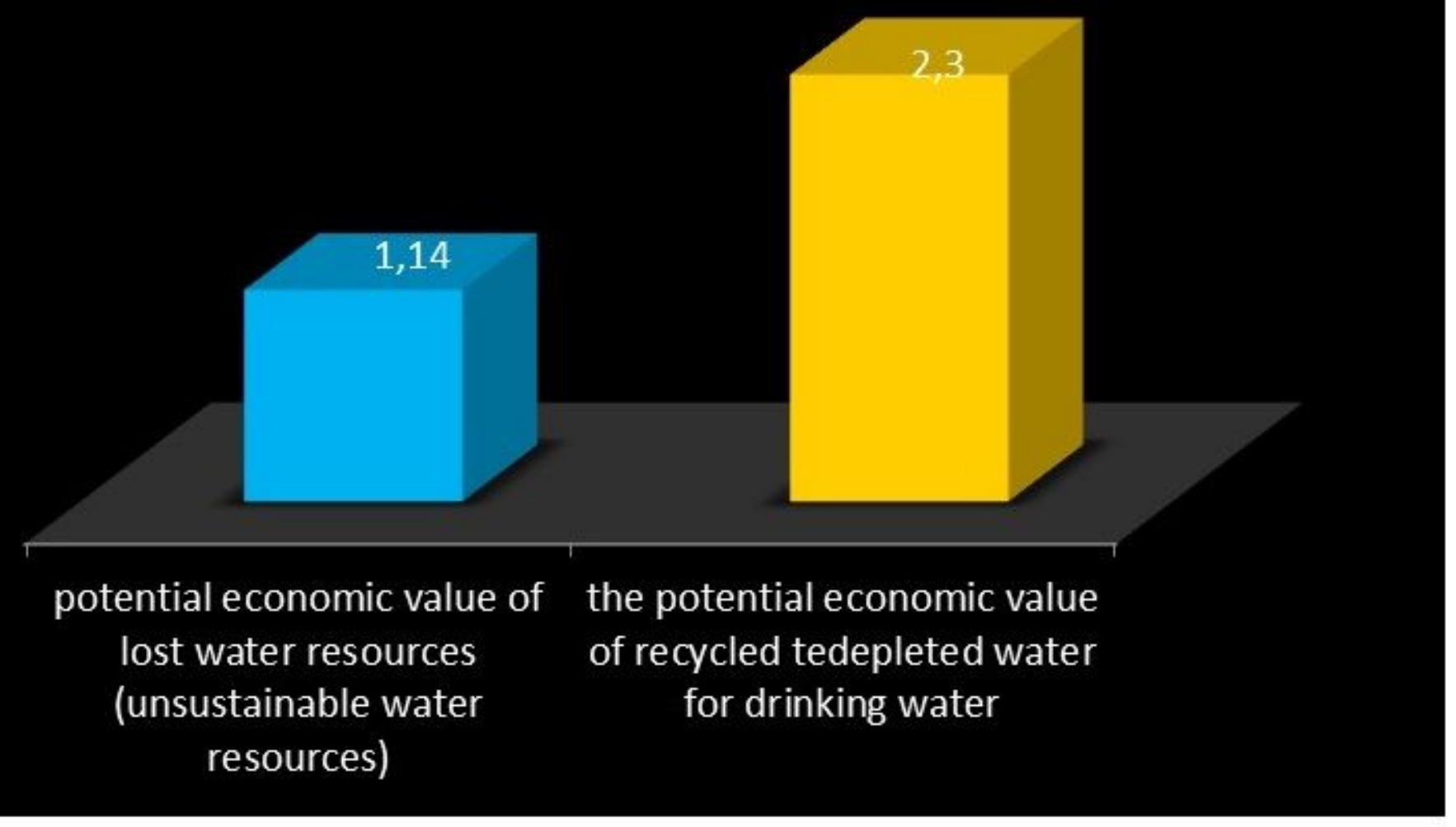

Figure 7

Potential economic value of water resources 
Man made

Environment

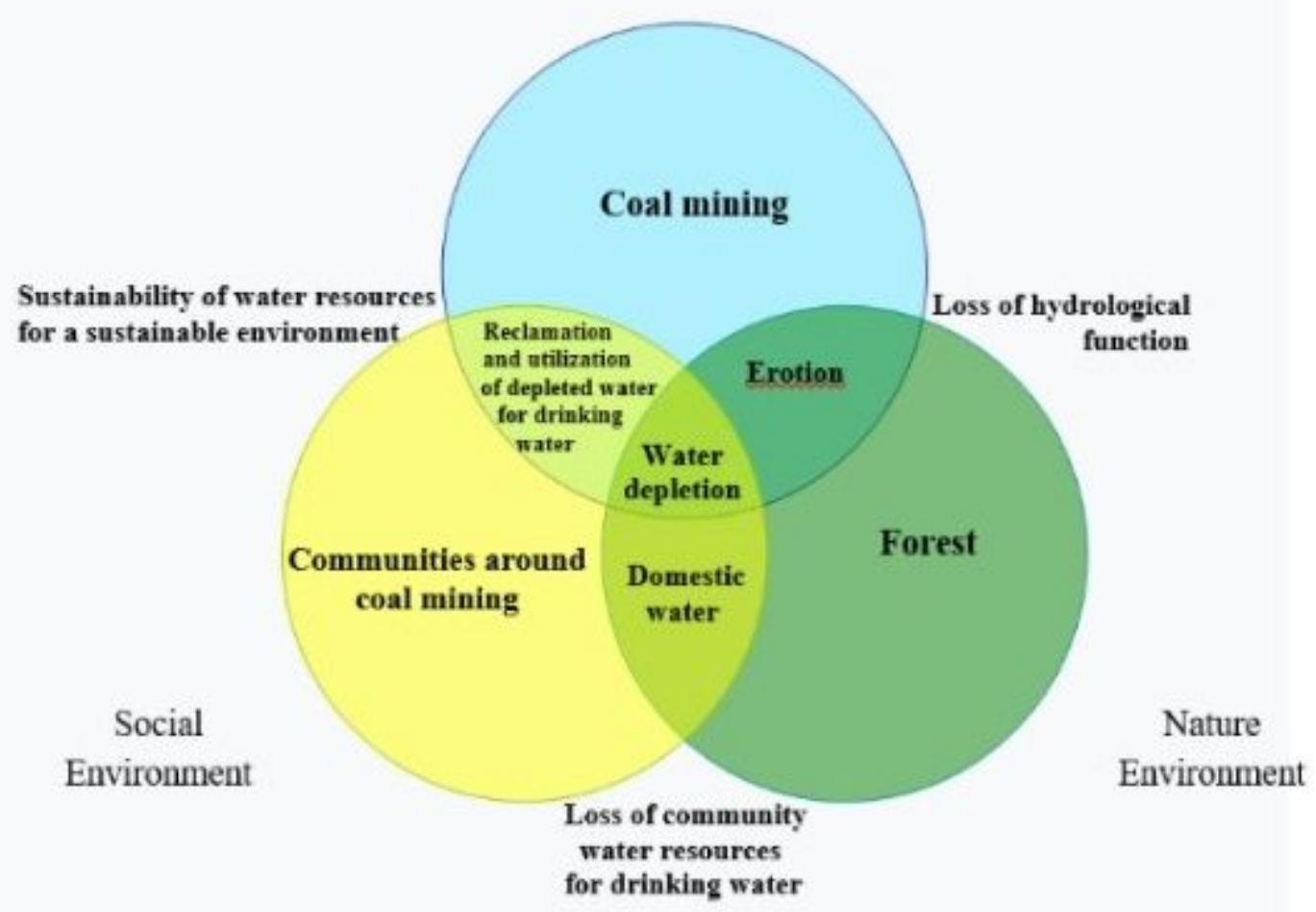

Figure 8

The concept of water resource sustainability for sustainable environment in the mining sector 